\title{
Developing Academic Writing Skills in EFL University Students Through Haiku Composition
}

\author{
El desarrollo de destrezas de escritura académica en estudiantado universitario de inglés a \\ través de la composición de haikus
}

\section{O desenvolvimento de habilidades de redação acadêmica entre estudantes universitários de inglês através da composição de haikus}

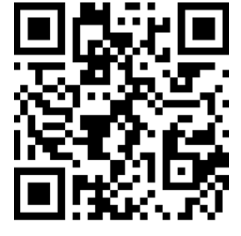

Juan José Santillán-Iñiguez Universidad de Cuenca

Cuenca, Ecuador

juan.santillan@ucuenca.edu.ec https://orcid.org/0000-0002-4968-1332

Fabián Darío Rodas-Pacheco
Universidad de Cuenca
Cuenca, Ecuador fabian.rodas@ucuenca.edu.ec https://orcid.org/0000-0001-8263-5015

Recibido • Received • Recebido: 28 / 01 / 2020

Corregido • Revised • Revisado: 28 / 09 / 2021

Aceptado • Accepted • Aprovado: 03 / 11 / 2021

\begin{abstract}
:
Background. Although there is empirical evidence to support the inclusion of poetry in the EFL classroom, the medium is rarely encountered in language learning environments. Aims. This study aimed to determine the influence of haiku composition tasks on developing academic writing skills of a group of TEFL majors at an Ecuadorian university. Method. The study was part of a larger research project (originally presented as a Master's degree dissertation), developed under a mixedmethod approach. This article reports the quantitative findings of the statistical analysis of results of two essay-based tests, administered before and after a six-week treatment that promoted haiku composition practices. Results. The findings determine a positive influence of haiku composition on the development of the academic writing skills of the participants in the study. Discussion. The main benefits of haiku composition in terms of academic writing skill development relate to the vocabulary enrichment and enhancement of linguistic competence, audience awareness, and writing process consciousness. These benefits are linked to the formal meter and reader-centeredness nature of haiku. The results encourage the inclusion of poetry-based creative writing tasks in EFL contexts; the evidence suggests that these activities are feasible and beneficial for motivated learners, particularly when framed within a student-centered process.
\end{abstract}

Keywords: Haiku composition; academic writing skills; EFL learners. 
http://doi.org/10.15359/ree.26-1.11

http://www.una.ac.cr/educare

educare@una.ac.cr

\begin{abstract}
Resumen:
Introducción. A pesar de la existencia de evidencia empírica para apoyar la inclusión de la poesía en el aula de inglés como lengua extranjera, el medio es raramente incluido en estos contextos de aprendizaje. Objetivo. El objetivo de la presente investigación fue determinar la influencia de la composición de haiku en el desarrollo de las destrezas de escritura académica de un grupo de treinta estudiantes de la Carrera de Lengua y Literatura Inglesa de una universidad ecuatoriana. Metodología. Este estudio fue parte de un proyecto más amplio (originalmente presentado como tesis de maestría), desarrollado mediante un enfoque de métodos mixtos. Este artículo reporta los resultados cuantitativos del análisis estadístico de los resultados de pruebas escritas, basadas en ensayos, que fueron aplicadas antes y después de una intervención de seis semanas, en las que la composición de haiku fue fomentada. Resultados. Los resultados el estudio demuestran que la composición de haiku tuvo un efecto beneficioso en el desarrollo de las destrezas de escritura académica del estudiantado participante del estudio. Discusión. Los principales beneficios de la composición de haiku con respecto al desarrollo de destrezas de escritura académica se relacionan con la adquisición de vocabulario y la mejora de la competencia lingüística y la conciencia de la audiencia y el proceso de escritura. Estos beneficios están conectados a la métrica y enfoque al público lector de los haiku. Los resultados motivan la inclusión de actividades de escritura creativa basadas en la poesía en los contextos de la enseñanza del inglés; la evidencia sugiere que estas actividades son posibles y favorables para estudiantado motivado, particularmente, cuando se enmarcan en un proceso centrado en su accionar.
\end{abstract}

Palabras claves: Composición de haiku; destrezas de escritura académica; estudiantes de inglés como lengua extranjera.

\title{
Resumo:
}

Introdução. Embora exista evidência empírica para apoiar a inclusão da poesia na sala de aula de inglês como língua estrangeira, raramente este meio é encontrado nos ambientes de aprendizado de idiomas. Objetivo. $\mathrm{O}$ objetivo deste estudo foi determinar a influência das tarefas de composição do haiku no desenvolvimento das habilidades de redação acadêmica de um grupo de trinta estudantes da carreira de Língua e literatura inglesa de uma universidade equatoriana. Metodologia. $O$ estudo fez parte de um projeto de pesquisa maior (apresentado originalmente como uma dissertação de mestrado), desenvolvido sob uma abordagem de métodos mistos. Este artigo apresenta os resultados quantitativos da análise estatística dos resultados de dois testes baseados em ensaios, administrados antes e após um trabalho de seis semanas, onde foi promovida as práticas de composição do haiku. Resultados. Os resultados determinam uma influência positiva da composição do haiku no desenvolvimento das habilidades de escrita acadêmica dos participantes do estudo. Debate. Os principais benefícios da composição do haiku em termos de desenvolvimento de habilidades de escrita acadêmica estão relacionados ao enriquecimento do vocabulário e aprimoramento da competência linguística, conscientização do público e do processo de escrita. Esses benefícios estão ligados à métrica e a centralização no leitor do haiku. Os resultados motivam a inclusão de atividades de escrita criativa com base na poesia em contextos de ensino de inglês; as evidências sugerem que essas atividades são possíveis e favoráveis para estudantes motivados, especialmente dentro de uma perspectiva centrado na sua ação.

Palavras-chave: Composição do haiku; habilidades de redação acadêmica; estudantes de inglês como língua estrangeira. 
http://doi.org/10.15359/ree.26-1.11

http://www.una.ac.cr/educare educare@una.ac.cr

\section{Background}

This article reports on the results of a research project that sought to examine the effects of poetry-based activities, specifically haiku composition, on the development of academic writing skills, with the aim of providing empirical evidence to support the decisions regarding the inclusion of this kind of activities in ESL/EFL contexts.

This paper presents an account of the research background regarding the inclusion of literature and poetry in the language classroom; then the methodology of the study is explained. The next section features the results of the research and discusses them on the basis of the theoretical and empirical evidence on the topic. Finally, conclusions and recommendations that spring from the findings of the study are provided in the last section.

There is a reported reluctance to include poetry-based tasks in ESL and EFL instruction. In fact, although Hişmanoğlu (2005), Spack (1985); and Khatib (2011) inform on a recent resurgence of interest in literature in the language classroom, poetry has continued to be excluded from these leaning environments (Khatib, 2011; Panavelil, 2011; Scrivener, 2011) suggest that the unwillingness to include poetry in EFL and ESL learning activities can be connected to the personal attitudes that both teachers and students have regarding the genre. Furthermore, as claimed by Hall (2005); Hanauer (2012) and lida (2012) the influence of the use of poetry in language learning has not been researched in depth, especially when compared to other dimensions of the field. Complementarily, it has been argued that the current focus on grammar and observable skills could place language learners "at a disadvantage when they have to use English in real-world situations" (lida, 2011, p. 1).

Furthermore, and dealing with the second variable of this study, Golkova and Hubackovab (2014) and Fareed etal. (2016) assert that the productive skills inherently have a greater complexity for language learners, particularly, as Sajid and Siddiqui (2015) argue, when academic tasks are considered. This circumstance and the already-mentioned lack of empirical studies on poetry and language instruction have established a research gap which this study has endeavored to attend. Consequently, the paragraphs to follow give an account of the research background of this study, its methodology, results, and conclusions.

\section{Literature Review}

The use and influence of literature in ESL/EFL instruction has seen two discrete stages. The first one concerns itself with the discussion and ensuing conclusion of practitioners' experience, and the second stage is connected to actual empirical research. Nkwetisama (2013) reports that, for almost 400 years, that is, between the 1400 s and the 1800 s, literature was employed when teaching classical rhetoric, i.e., when developing inquiry and communicative skills. In addition, Larsen-Freeman \& Anderson (2011) mentions that literature was a key element of the GrammarTranslation Method. However, as Nkwetisama (2013) states, within these methodological frameworks, literary texts were not seen as a means for developing communicative competence. 
http://doi.org/10.15359/ree.26-1.11

http://www.una.ac.cr/educare

educare@una.ac.cr

The advent of the 1800s saw the shift of focus of language instruction towards accuracy. This transition marked the beginning of the exclusion of literature from the language classroom (Nkwetisama, 2013). Moreover, as Mackay (1982) suggests, in the last decades of the XX century, achieving professional and academic goals became the trend in language instruction; consequently, the crucial significance of literary texts "faded as linguistics became the focal point of language programs" (Widdowson, 1982, citado por Spack, 1985, p. 704).

Nevertheless, Paran (2008) and Spack (1985) remark that a concurrent interest in the value of literature as material for language teaching began in the eighties. Notwithstanding, since that resurgence, teachers have usually thought of literary texts as "a source of activities, as 'material', with too little concern for the wider curricular issues" (Hall, 2005, p. 47). Accordingly, Bloemert et al. (2019) claim that, in spite of current attempts, a harmonious integration of literature in language instruction curricula has not been achieved.

Another characteristic of this current interest in literature relates to its lack of empirical evidence. According to Hall (2005), much of the arguments in favor of including literary texts in EFL and ESL contexts are taken from first language environments, or, as Paran (2008) suggests, they are developed departing from instructors' personal experiences. It is important to highlight that this shortage of research becomes more latent when dealing with poetry (Hanauer, 2010; lida, 2012).

However, research on the field has been carried out; therefore, it is necessary to become acquainted with the reported advantages of the inclusion of literature, especially, poetry, in the language classroom. Several authors have studied the influence of including poetry in ESL and EFL instruction. These authors have identified several benefits of this inclusion, which cover various aspects of language instruction. This information is summarized in Table 1.

Table 1: Reported advantages of the inclusion of literature and poetry in ESL/EFL instruction

\begin{tabular}{ll}
\hline \multicolumn{1}{c}{ Advantage } & Authors \\
\hline Authentic language model provision & Lazar (1993) \\
Vocabulary enrichment & Nation (2005) \\
& Kırkgöz (2008) \\
& Panavelil (2011) \\
& Scrivener (2011) \\
Development of the writing skill & Hişmanoğlu (2005) \\
& Collie and Slater (as cited in Panavelil, 2011) \\
Development of the reading skill & Kong (2010)
\end{tabular}

continúa 


\begin{tabular}{ll}
\hline \multicolumn{1}{c}{ Advantage } & Authors \\
\hline Development of oral-aural skills & Lazar (1993) \\
Grammar improvement & Harmer (2010) \\
& Lazar (1993) \\
Panavelil (2011) & Khatib (2011) \\
Motivation enhancement & Lazar (1993) \\
& Kong (2010) \\
& Scrivener (2011) \\
& Panavelil (2011) \\
& Hanauer (2012) \\
\hline
\end{tabular}

Note: Table designed and developed by the authors of this paper.

It is now necessary to discuss the research background of this study. Pushpa and Savaedi (2014) analyzed the impact of including poetry in autonomous EFL courses. The authors concluded that incorporating poetry-based tasks in the language classroom has a beneficial effect on performance. In addition, Pushpa and Savaedi (2014) argue that, because of the universality of its topics, poetry promotes self-identification and interest enhancement in learners, which in turn facilitate creativity and freedom of expression.

Concerning poetry writing in language-learning contexts, Hanauer (2010), after having carried of a corpus analysis of 844 poems written by ESL learners, identified three common characteristics: a) short texts, b) simple vocabulary, and c) reliance on imagery. As a result, Hanauer (2010) concluded that, despite generalized beliefs, writing poetry is not an unsurmountable or even difficult task for motivated students, particularly those of advanced levels.

For his part, Liao (2012) examined the connection between the identified value of poetry writing and the experiences of a group of TESOL graduate students in an American university. The findings of his study led Liao (2012) to assert that writing poems cultivates self-expression and discovery, as well as emotional release. In terms of Communicative Competence, Liao (2012) concluded that poetry writing promotes the development of linguistic knowledge and skills, particularly, vocabulary acquisition. Liao (2012) claimed that, by writing poetry, students of a second or foreign language are prompted to "to embrace the authorship and ownership of their writing and the English language, and see themselves as multilingual writers" (p. 97).

In the same line of research, Chamcharatsri (2013) analyzed the experiences of four ESL students from Thailand, as they expressed love through poems, which were written in both English and Thai. Chamcharatsri (2013) argued that, despite the acknowledged difficulty of 
http://doi.org/10.15359/ree.26-1.11

http://www.una.ac.cr/educare

educare@una.ac.cr

the task, the participants of the study were able to successfully communicate thoughts and emotions through original poetic texts. According to this author, one effect of poetry writing is shifting the focus of their pieces from form to content, which promotes the awareness of the value of English as a medium for self-expression.

With regard to haiku composition, it is first important to briefly explain the genre. Haiku are short 17-syllable poems of Japanese origin. The formal characteristics of this type of poem include the use of syllabic meter that organizes the poem in three lines, following a 5-7-5 pattern. Moreover, haiku have one more formal element of importance: kireji, i.e., a division, signaled by a word or punctuation mark, at the end of the second line of the poem. As regards the content characteristics of haiku, one has to mention two: a) kigo, or the reference, through evocative words of phrases, to the seasons; and b) the reader-centeredness nature of the poem, that is, the possibility of different individual interpretations of the poem that depart from the readers' experience.

lida (2011) considered two areas of research: a) the influence of the practice on ESL/EFL academic literacy and b) the attitudes, perceptions, and emotions of students towards writing haiku. 20 Japanese EFL students participated in lida's (2011) research. The design of the study comprised the administration of pre and post-tests based on essay writing, as well as carrying out personal interviews before and after a treatment of six weeks. In addition, lida (2011) examined reflection forms, weekly journal entries, and a collection of 10 haiku produced by each participant.

The analysis of the tests and the haiku produced by the participants shows that creative writing practices, such as haiku composition, facilitate the enhancement of academic writing skills in EFL students. With regard to the subjective value of the practice, lida (2011) remarks that the study's participants recognized the difficulty of haiku composition in a foreign language; however, the author argues that most participants acknowledged the benefits of poetry writing in terms of vocabulary enrichment, personal expressiveness, and improvement of literacy skills which can be transferred to other non-creative genres.

Additionally, two complementary research projects originated from lida's (2011) seminal study. lida's (2012) research -which included the same subjects, following a similar design, as the 2011 project- mainly emphasized the analysis of the participants' perceptions towards haiku composition. The findings evinced affirmative attitudes with regard to writing haiku, which is recognized as a beneficial task for language learners, particularly in terms of vocabulary acquisition. These conclusions agree with the findings from previous research (Chamcharatsri, 2013; Hanauer, 2010; lida, 2011; Liao, 2012).

In a second complementary project, lida (2016) carried out a case study of a Myanmarese EFL student learning English in Japan. The results concluded that poetry composition promotes 
http://doi.org/10.15359/ree.26-1.11

http://www.una.ac.cr/educare educare@una.ac.cr

communicative practice and that it bestows these opportunities with subjective value, hence facilitating self-discovery. Moreover, it is noteworthy to mention that lida's research understands voice development and self-expression as crucial means for the enhancement of academic writing skills in a foreign language.

\section{Methodology}

As mentioned before, this article reports on the quantitative aspect of a larger study carried out under the Mixed-Methods Approach, which was originally presented as a Master's Degree Dissertation entitled Haiku composition and the development of academic writing skills (Santillán Iñiguez, 2018). Consequently, the section to follow describes the design for the statistical analysis of the results of pre and post essay-based tests applied at the beginning and at the end of a six-week intervention.

Participants. 30 Teaching English as a Foreign Language (TEFL) majors at an Ecuadorian university -8 males and 22 females- were part of the study. Throughout the first semester (September-February) of the 2017-2018 academic year, the subjects took the sixth-semester Conversation and Composition course. The selection of this group of participants obeyed the characteristics of convenience sampling, that is, they were selected because they met specific "practical criteria, such as easy accessibility, geographical proximity, availability at a given time, [and] ... willingness to participate" (Etikan, Abubakar, \& Sunusi, 2016, p. 2). As the researchers belong the faculty staff of the TEFL Major of the university where the research was carried out, access to this particular unit of analysis was facilitated. The suitability of this group relied on the fact that, at this level, TEFL students at this university are presumed to have achieved a B1 level, according to the Common European Framework of Reference for Languages (CEFR). This level was established by the assessment methods and instruments developed and used by the English Language and Literature Major of the university where the study was developed. Furthermore, the contents and expected outcomes of the Conversation and Composition course corresponded to the characteristics of this study.

Data Collection. The project used first-hand data gathering instruments, that is, two short essays written in English before and after the study's treatment.

To determine the academic writing skills of the subjects of the study before the intervention, a pre-test was administered. Based lida's (2011) research design, the pre-test asked students to compose an argumentative essay on a specific topic. Aside from the agreement with the type of instruments that were used in previous research on the topic, the decision of employing the composition of an argumentative essay for collecting data obeys to the straightforward connection of the instrument to the dependent variable of this study: academic writing skills. The participants of the study were separated in two groups ( $A$ and $B$ ), each receiving a writing 
http://doi.org/10.15359/ree.26-1.11

http://www.una.ac.cr/educare

educare@una.ac.cr

prompt -adapted from lida's (2011) study- about a different topic. The writing task asked students to present and argumentatively defend a point of view on a topic related to higher education. The time limit for the task was an hour; however, for the purposes of the research, a minimum word count was not specified.

After this initial assessment, the formal characteristics and writing process of the haiku were explained to the students in the first of six weekly creative writing lessons. The study's intervention was based on the haiku composition protocol developed by lida (2010), which encompasses the following stages: a) review the concept of haiku, b) collection material for haiku through sensorial activation, c) composition per se, d) peer editing, and e) publication. Each weekly lesson consisted of two 60-minute sessions in class and one hour of autonomous composition at home.

After the intervention, the students were asked to compose a second argumentative essay, the post-test. The participants were divided in the same groups as in the pre-test, but this time, they received the writing prompt that, during the first test, was given to the other group. This measure was taken in order to keep the post-test from being affected by a previous acquaintance with the topic of the essay.

Data analysis. To guarantee consistency and dependability, both tests were marked by two TEFL faculty staff members of the university where the research took place, who, aside from marking the tests, did not participate in another other stage of the study. To mark the essay-based tests, a validated B1 rubric for writing from the University of Cambridge (Lim, 2012) was employed, which measured four criteria on the basis of a 0 - 5 scale: organization, communicative achievement, content, and language. The test results were statistically analyzed by a professional in the area using the specialized software SPSS, 22 version. This analysis yielded descriptive and inferential findings.

The descriptive analysis took into account Means (M) and Standard Deviations (SD). The first element employed the rubric criteria to reveal tendencies in the results. Standard Deviations, for their part, showed the degree of variation and dispersion that existed among the mean of each criterion. Moreover, this analysis also considered the number of mistakes related to grammar, spelling, and punctuation that were identified in the pre and post - tests.

For the inferential analysis, the Shapiro Wilk Nonparametric Test was used to determine data distributions. This statistical analysis employed the $p$ value as the result of probabilities to ascertain whether the haiku writing treatment altered the initial condition of the students in the post-intervention assessment. Consequently, it was determined that the hypothesis regarding the impact of the haiku writing on the development of academic writing skills was to be confirmed with a $p$ value inferior to $0.05(p<0.05)$. 
http://doi.org/10.15359/ree.26-1.11

\section{Results}

This section provides a statistical comparison of the pre and post-test results in terms of their means and standard deviations of each one of the rubric criteria, as well as of their sum. The same procedure was employed for the mistake count comparison between the tests.

A performance comparison between the pre and post-intervention tests is shown in Table 2, which also includes the mean differences between the two tests and the $p$ value for each criterion of the rubric.

Table 2: Pre and post-test results comparison

\begin{tabular}{lccccccc}
\hline & \multicolumn{2}{c}{ Pre-test } & \multicolumn{2}{c}{ Post-test } & \multicolumn{2}{c}{ Difference } & \multirow{2}{*}{ p value } \\
\cline { 2 - 6 } & $\mathrm{M}$ & S.D. & $\mathrm{M}$ & S.D. & $\mathrm{M}$ & S.D. & \\
\hline Content & 3.33 & 1.49 & 4.13 & 0.73 & 0.80 & 1.21 & 0.001150 \\
Communicative achievement & 3.03 & 1.30 & 3.80 & 0.81 & 0.77 & 0.90 & 0.000062 \\
Organization & 3.03 & 1.40 & 3.97 & 0.85 & 0.93 & 1.05 & 0.000036 \\
Language & 3.33 & 1.30 & 4.20 & 0.76 & 0.87 & 0.97 & 0.000036 \\
Sum & 12.73 & 5.19 & 16.10 & 2.63 & 3.37 & 3.37 & 0.000007 \\
\hline
\end{tabular}

Note: Table designed and developed by the authors of this paper. Content (t 3.607, df 29, p .001), Communicative achievement (t 4.678, df 29, p .000), Organization (t 4.877, df 29, p .000), Language (t 4.878, df 29, p .000), Sum (t 5.475, df 29, p .000).

The contrast between the pre and post-intervention tests evinced a significant increase in each criterion and in their total sum. As a matter of fact, the mean difference between the two tests in the Content criterion was 0.8; in the Communicative achievement criterion, the difference was 0.77; in Organization, it was 0.93; and finally, in Language, 0.87. All in all, the mean difference between the sum of the all criteria was 3.37 (SD 3.37). The statistical analysis, moreover, revealed that the increase was significant in all cases, given that their $p$ values were less than 0.05 . Therefore, statistical evidence was found to confirm a positive impact of haiku writing practices on academic writing skills development.

On the other hand, as shown in Table 3, it was determined that the number of identified mistakes decreased in the post-test. 
http://doi.org/10.15359/ree.26-1.11

http://www.una.ac.cr/educare

educare@una.ac.cr

Table 3: Mistake count comparison

\begin{tabular}{lccccccc}
\hline & \multicolumn{2}{c}{ Pre-test } & \multicolumn{2}{c}{ Post-test } & \multicolumn{2}{c}{ Difference } & \multirow{2}{*}{ p value } \\
\cline { 2 - 6 } & M & S.D. & M & S.D. & M & S.D. & \\
\hline Spelling & 6.27 & 3.65 & 4.03 & 3.86 & 2.23 & 5.06 & 0.022213 \\
Grammar & 6.50 & 3.95 & 4.40 & 4.25 & 2.10 & 4.05 & 0.008224 \\
Punctuation & 2.20 & 2.12 & 2.07 & 1.87 & 0.13 & 2.96 & 0.806631 \\
Sum & 14.97 & 7.19 & 10.50 & 7.13 & 4.47 & 7.62 & 0.003242 \\
\hline
\end{tabular}

Note: Table designed and developed by the authors of this paper. Spelling ( $2.416, \mathrm{df} 29, \mathrm{p} .022$ ), Grammar (t 2.837, df 29, p .008), Punctuation (t .247, df 29, p .807), Sum (t 3.209, df 29, p .003).

Specifically, students made noticeably fewer spelling and grammar mistakes. Concerning the first aspect, the difference was 2.23, and in Grammar, it was 2.10. The significance of both the difference in both aspects was confirmed by a $p$ value that was lower than 0.05 . Nevertheless, concerning punctuation, the statistical analysis did not reveal a significant change, as the difference was only of 0.13 , with a p value of 0.80 . Finally, the statistical comparison of the sum of the mistake count analyses of both tests evidenced an important improvement, the total difference being of 4.46 , with a p value of 0.003

Lastly, the behavior of the results of the tests applied before and after the treatment is portrayed in Figure 1, which was developed on the basis of the total means and standard deviations of both tests.

Figure 1: Bar diagram of pre and post-test results

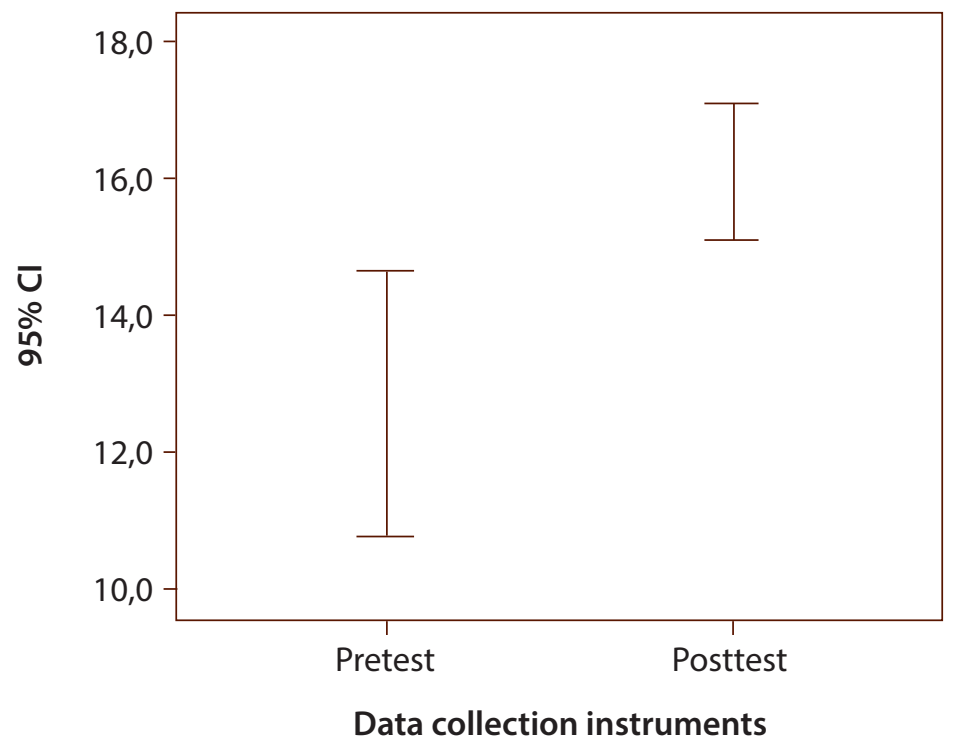

Note: Figure designed and developed by the authors of this paper. 
http://doi.org/10.15359/ree.26-1.11

http://www.una.ac.cr/educare educare@una.ac.cr

The Bar Diagram of the test results reveals the positive influence of haiku writing when developing academic writing skills. The contrast of the results of the tests makes this conclusion evident, as the total mean in the pre-test was two points lower than that of the post test. Moreover, the pre-test results showed more variation (SD 4.42) than the post-test ones (SD 2.63)

\section{Discussion}

The immediate inference that emerges from the statistical analysis of the test results is that haiku composition practices had a positive influence on developing the academic writing skills of the TEFL majors that participated in this study. Furthermore, the $p$ value of all the assessed criteria indicates that this impact was significant.

When comparing the results of the criteria of the rubric, it was ascertained that the Organization criterion displayed the most significant difference between the pre and postintervention tests: 0.93 . The Language criterion was second in this regard with a difference of 0.87. However, one has to take into account that the Standard Deviation is lower in Language. This circumstance highlights the positive influence of haiku composition on the Language criterion, as the individual results hold less variance between the highest to the lowest scores. The benefit in terms of Organization ought to be understood on an increased attentiveness towards the writing process caused by composing haiku (lida, 2010). This increased awareness can be linked to the haiku writing process and the editing efforts that it encompasses. Moreover, the improvement in the Organization criterion can also be connected to the other reported advantages of haiku writing, such as the enhancement of writing skills and knowledge which are specific to a genre, and the transfer of definite literacy skills, as reported by lida (2011).

As indicated by the rubric descriptors for the Language criterion (see Appendix A), the enhancement in this area is mainly related to the vocabulary enrichment, mistake reduction, and grammatical competence development. As a consequence, the results of this criterion directly advocate for the idea, discussed by many authors, that poetry writing practices prompt vocabulary (lida, 2011, 2012; Kırkgöz, 2008; Liao, 2012; Panavelil, 2011; Scrivener, 2011). Similarly, one should consider that vocabulary enhancement has been ascertained as one significant contribution of haiku writing in EFL contexts (lida, 2011). As argued by lida $(2011,2012)$ and Hanauer (2012), this vocabulary enrichment has two main causes: the structural constrains of haiku, namely the 5-7-5 syllable pattern, and the meaningful use of language items that poetry composition facilitates.

With regard to grammatical competence, the statistical analysis of the test results revealed that writing haiku did have a beneficial influence on accuracy. These results, furthermore, are in straightforward agreement with what has been reported in the pertinent literature concerning linguistic awareness and grammatical competence development (lida, 
http://doi.org/10.15359/ree.26-1.11

http://www.una.ac.cr/educare

educare@una.ac.cr

2011; Kırkgöz, 2008; Lazar, 1993; Panavelil, 2011). The mistake count statistical analysis of also confirms the positive effect of haiku composition on accuracy, as the categories with the greatest contrast between the pro and post-test were grammar and spelling. The reason behind this circumstance can be found on a heightened awareness of the writing process and meaningful language use -practice- that poetry composition is prone to encourage.

The results of the Content and Communicative achievement criteria and Content, are also significant, as confirmed by their $p$ value. Concerning Content, the betterment in this criterion is the explained in the consequential self-expression that, as lida $(2011,2012)$ claims, haiku writing -and poetry composition in general-facilitates. Furthermore, as the same author also suggests, by composing poems in a structurally defined medium as haiku, language learners are likely to acquire expressive freedom, which becomes latent when students write in genres, such as essays, that do not feature the formal constraints of poetry, e.g., meter, rhyme, stanza organization, etc. Put in another way, after having written in meter, students expressiveness is heightened when carrying out less structurally defined writing tasks. Moreover, advancement in Content is also prompted by other reported benefits of poetry composition, particularly, vocabulary enrichment, greater audience awareness, and improved consciousness of the writing process. For its part, the rationale behind furtherance in Communicative achievement is an alleged audience awareness enhancement, which, according to lida (2011), haiku writing encourages. The reason for this heightening the attentiveness towards audience when writing haiku is the reader-centeredness of the medium; that is, as in any other form of poetry, the conveyance of meaning in haiku rests on figurative language; therefore, the writer should constantly consider the possibilities of interpretation that a potential reader may have. Additionally, as mentioned above, literacy skill transfer is one important feature of poetry writing; so the consideration toward that writing haiku develops is likely to be present when writing other types of texts. Having a greater attention towards the audience of a text allows language learners to identify, consider, and observe the specific conventions held by the speech community for whom a text is produced.

\section{Conclusions}

The results of the pre-test and a careful examination of the literature on the topic allows one to assert that, as argued by Hanauer (2012) and lida (2011), that the overemphasis on the structural dimensions of communicative competence that characterized current second and foreign language instruction produces a heavy reliance on observable skills; in other words, proficiency is more readily measured on the basis of what instructors can read and hear; this circumstance is prone to cause difficulties in real-life performance. In the particular case of this study, the main deficiencies that were identified in the pre-test related to the Organization and Communicative Achievement rubric criteria, which implied problems in terms of self-expression and attentiveness towards the audience. 
http://doi.org/10.15359/ree.26-1.11

Concerning the comparison of the results and mistake count analysis of the pre and post-tests, significant performance differences were identified, the Organization and Language criteria being the dimensions were more latent contrast was ascertained. Consequently, one can suggest that haiku composition has a beneficial influence on audience awareness, writing process consciousness, and linguistic competence. The conclusion that ensues, therefore, is that haiku composition practices had a positive effect on the development of the academic writing skills of the TEFL majors involved in this research study; in fact, the statistical analysis, specifically the $p$ value of the results, indicates that this beneficial influence was significant.

Besides, the fact that the participants of the study were able to complete the haiku composition tasks reveals that -contrary to the generalized beliefs about its complexity-poetry writing is a feasible undertaking for language learners. Furthermore, the results of this research, which add to the corpus of empirical evidence of the topic, clearly demonstrate that poetry composition -specifically, haiku writing- is not only achievable but also advantageous for language learners.

The statistical analysis of the results of the pre and post-intervention tests suggest that the most significant contribution of haiku writing to the advancement of academic writing skills is vocabulary acquisition. This conclusion is corroborated by the findings of various research projects (lida, 2011, 2012; Kırkgöz, 2008; Liao, 2012) and by the theoretical assumption on the topic (Hanauer, 2012; Lazar, 1993; Nation, 2005; Panavelil, 2011). Furthermore, the beneficial influence of haiku -and poetry- writing on vocabulary enrichment has a dual nature. For one part, the practice allows, and demands, students to look for, encounter, meaningfully use new words in their composition. The second trait of the vocabulary acquisition facilitated by haiku writing relates to an enhanced consciousness of the connotational value of the words used in the poem, which derives from the reader-centered nature of haiku. These two aspects of vocabulary acquisition are to be understood in light of the meaning negotiation (lida, 2011) in which writers of haiku -and any other genre of poetry- have to engage in order to observe the metrical constrains of the medium, i.e., a 5-7-5 syllabic pattern.

It is imperative to remark that, despite the specificity of the inquire of this study, its findings evince that haiku composition can be thought to have a holistic positive influence on communicative competence; that is, the benefits of haiku writing include aspects of proficiency -audience awareness, vocabulary acquisition, self-expression, and accuracy- that have a permeating influence on all aspects of language learning.

To finalize, it is appropriate to provide some recommendations that can be made on the basis of the findings of this study. As regards the incorporation of literature in language instruction, the research background and the findings of this study prompt one to advocate for the inclusion of poetry in ESL and EFL environments. This inclusion, when appropriately carried 
http://doi.org/10.15359/ree.26-1.11

http://www.una.ac.cr/educare

educare@una.ac.cr

out, is likely to provide students with opportunities for self-expression, which is of special importance in learning environments that have become dehumanized (Hananuer, 2012).

Furthermore, because of the personal nature of poetry, creative writing tasks based on this literary medium can prompt self-understanding, which is crucial for the achievement of an authentic proficiency that is marked by meaningful and personal self-expression (Hanauer, 2012). Nevertheless, one has to bear in mind that the value and effectiveness of poetry-based activities relies upon selecting appropriate texts and tasks, as well as upon establishing suitable pre, while, and post-writing (or reading) sequences for the activities.

Moreover, the findings of this study, along with the pertinent empirical evidence, highlight the importance of making informed decisions in regard to lesson planning and even curriculum design; such decisions should not be prompted by generalized beliefs, even if they agree with the teacher's own experience, as there is a risk of discarding tasks and materials, such as the one that was the subject of this study, with empirically proved benefits for learners. Lastly, it is recommended that more research be carried out regarding the effect that creative writing practices have on the development of English macro-skills, especially in Latin American contexts, where there is a relative want of research on the topic.

\section{Declaración de Material complementario}

Este artículo tiene disponible, como material complementario:

-La versión preprint del artículo en https://doi.org/10.5281/zenodo.4414895

\section{References}

Bloemert, J., Paran, A., Jansen, E., \& van de Grift, W. (2019). Students' perspective on the benefits of EFL literature education. The Language Learning Journal, 47(3), 371-384. https://doi.org /10.1080/09571736.2017.1298149

Chamcharatsri, P. B. (2013). Poetry writing to express love in Thai and in English: A second language (L2) writing perspective. International Journal of Innovation in English Language 2(2), 141-157. https://www.academia.edu/6237780/Poetry writing to express love in Thai and in English Second language L2 writing perspective

Fareed, M., Ashraf, A., \& Bilal, M. (2016). ESL learners' writing skills: Problems, factors and suggestions. Journal of Education \& Social Sciences 4(2), 83-94. 10.20547/jess0421604201

Golkova, D. \& Hubackovab, S. (2014). Productive skills in second language learning. Procedia Social and Behavioral Sciences, 143, 477-481. https://doi.org/10.1016/j.sbspro.2014.07.520

Hall, G. (2005). Literature in language education. Palgrave Macmillan. https://doi. org/10.1057/9780230502727 
http://doi.org/10.15359/ree.26-1.11

http://www.una.ac.cr/educare educare@una.ac.cr

Hanauer, D. I. (2010). Poetry as research: Exploring second language poetry writing. Amsterdam: John Benjamins. https://doi.org/10.1075/lal.9

Hanauer, D. I. (2012). Meaningful literacy: Writing poetry in the language classroom. Language Teaching, 45(1), 105-115. https://doi.org/10.1017/S0261444810000522

Harmer, J. (2010). How to teach english. Pearson.

Hişmanoğlu, M. (2005). Teaching English through literature. Journal of Language and Linguistic Studies, 1(1), 53-66. http://www.jlls.org/index.php/jlls/article/viewFile/6/7

Etikan, I., Abubakar Musa, S., \& Sunusi Alkassim, R. (2016). Comparison of convenience sampling and purposive sampling. American Journal of Theoretical and Applied Statistics, 5(1), 1-4. 10.11648/j.ajtas.20160501.11

lida, A. (2010). Developing voice by composing Haiku: A social-expressivist approach for teaching haiku writing in EFL contexts. English Teaching Forum, 48(1), 28-34. https:// americanenglish.state.gov/files/ae/resource files/10-48-1-e.pdf

lida, A. (2011). Revisiting Haiku: The contribution of composing haiku to L2 academic literacy development [Doctoral dissertation]. https://thehaikufoundation.org/omeka/items/ show $/ 2828$

lida, A. (2012). Writing haiku in a second language: Perceptions, attitude, and emotions of second language learners. Sino-US English Teaching, 9(9), 1472-1485. https://www.researchgate. net/publication/327891414 Writing Haiku in a Second Language Perceptions Attitudes and Emotions of Second Language Learners

lida, A. (2016). Poetic identity in second language writing: Exploring an EFL learner's study abroad experience. Eurasian Journal of Applied Linguistics, 2(1), 1-14. https://ejal.info/ poetic-identity-in-second-language-writing-exploring-an-efl-learners-study-abroadexperience/

Khatib, M. (2011). A new approach to teaching English poetry to EFL students. Journal of Language Teaching and Research, 2(1), 164-169. https://doi.org/10.4304/jltr.2.1.164-169

Kırkgöz, Y. (2008). Using poetry as a model for creating English poems. Journal of Language and Linguistic Studies, 4(2), 94-106. http://www.jlls.org/index.php/jlls/article/view/69/69

Kong, F. (2010). On the effectiveness of applying English poetry to extensive reading teaching. Journal of Language Teaching and Research, 1(6), 918-921. https://doi.org/10.4304/ jltr.1.6.918-921

Larsen-Freeman, D. \& Anderson, M. (2011). Techniques \& principles in language teaching (3rd ed.). Oxford University Press. 
http://doi.org/10.15359/ree.26-1.11

http://www.una.ac.cr/educare

educare@una.ac.cr

Lazar, G. (1993). Literature and language teaching: A guide for teachers and trainers. Cambridge University Press. https://doi.org/10.1017/CBO9780511733048

Liao, F. Y. (2012). ESL students' writing experiences and perceived poetry writing ability (Master's thesis). https://www.proquest.com/openview/eb6880d35f04515a2363171f005297ca/1? pq-origsite $=$ gscholar $\& \mathrm{cbl}=18750$

Lim, G. (2012). Developing and validating a mark scheme for writing. Research Notes (49), 6-10. https://www.cambridgeenglish.org/images/23166-research-notes-49.pdf

Mackay, S. (1982). Literature in the ESL classroom. TESOL Quarterly, 16(4), 529-526. https://doi. org/10.2307/3586470

Nation, P. (2005). Teaching vocabulary. The Asian EFL Journal, 7(3), 47-54. https://www.asian-efljournal.com/sept 05 pn.pdf

Nkwetisama, C. M. (2013). Literature and TEFL: Towards the reintroduction of literatures in English in the francophone secondary school curriculum in Cameroon. International Journal of Applied Linguistics \& English Literature 2(6), 169-178. https://doi.org/10.7575/ aiac.ijalel.v.2n.6p.169

Panavelil, A. (2011). Teaching poetry in an EFL/ESL class: An integrative and communicative approach. ELT Voices India: International Journal for Teachers of English, 1(3), 11-20. https:// eltvoices.in/access-journal/volume-i/issue-iii/

Paran, A. (2008). The role of literature in instructed foreign language learning and teaching: An evidence-based survey. Language Teaching, 41(4), 465-496. https://doi.org/10.1017/ $\underline{\text { S026144480800520X }}$

Pushpa, V. K. \& Savaedi, S. Y. (2014). Teaching poetry in autonomous ELT classes. Procedia - Social and Behavioral Sciences 98, 1919-1925. https://doi.org/10.1016/j.sbspro.2014.03.623

Sajid, M. \& Siddiqui, A. (2015). Lack of academic writing skills in english language at higher education level in Pakistan: Causes, effects and remedies. International Journal of Language and Linguistics, 2(4), 174-186. http://ijllnet.com/journals/Nol 2 No 4 October 2015/20.pdf

Santillán Iñiguez, J. J. (2018). Haiku composition and the development of academic writing skills [Master's thesis]. Universidad Técnica de Ambato. https://repositorio.uta.edu.ec/ handle/123456789/27890

Scrivener, J. (2011). Learning teaching: The essential guide to english language teaching (3rd ed.). Macmillan.

Spack, R. (1985). Literature, reading, writing, and ESL: Bridging the gaps. TESOL Quarterly, 19(4), 703-725. https://doi.org/10.2307/3586672 
http://doi.org/10.15359/ree.26-1.11

http://www.una.ac.cr/educare educare@una.ac.cr

Appendix A: B1 Writing Rubric

\begin{tabular}{|c|c|c|c|c|}
\hline B1 & Content & $\begin{array}{l}\text { Communicative } \\
\text { achievement }\end{array}$ & Organization & Language \\
\hline \multirow[t]{3}{*}{5} & \multirow[t]{3}{*}{$\begin{array}{l}\text { All content is relevant to the } \\
\text { task. Target reader is fully } \\
\text { informed. }\end{array}$} & \multirow[t]{3}{*}{$\begin{array}{l}\text { Uses the conventions } \\
\text { of the communicative } \\
\text { task to hold the target } \\
\text { reader's attention } \\
\text { and communicate } \\
\text { straightforward ideas. }\end{array}$} & \multirow[t]{3}{*}{$\begin{array}{l}\text { Text is generally } \\
\text { well organized and } \\
\text { coherent, using a } \\
\text { variety of linking } \\
\text { words and cohesive } \\
\text { devices. }\end{array}$} & $\begin{array}{l}\text { Uses a range of } \\
\text { everyday vocabulary } \\
\text { appropriately, } \\
\text { with occasional } \\
\text { inappropriate use of less } \\
\text { common lexis. }\end{array}$ \\
\hline & & & & $\begin{array}{l}\text { Uses a range of simple } \\
\text { and some complex } \\
\text { grammatical forms with a } \\
\text { good degree of control. }\end{array}$ \\
\hline & & & & $\begin{array}{l}\text { Errors do not impede } \\
\text { communication. }\end{array}$ \\
\hline 4 & \multicolumn{4}{|c|}{ Performance shares features of bands 3 and 5} \\
\hline \multirow[t]{3}{*}{3} & \multirow[t]{3}{*}{$\begin{array}{l}\text { Target reader is on the whole } \\
\text { informed. }\end{array}$} & \multirow[t]{3}{*}{$\begin{array}{l}\text { Uses the conventions of } \\
\text { the communicative task } \\
\text { in generally appropriate } \\
\text { ways to communicate } \\
\text { straightforward ideas. }\end{array}$} & \multirow[t]{3}{*}{$\begin{array}{l}\text { Text is connected and } \\
\text { coherent, using basic } \\
\text { linking words and a } \\
\text { limited number of } \\
\text { cohesive devices }\end{array}$} & $\begin{array}{l}\text { Uses everyday } \\
\text { vocabulary generally } \\
\text { appropriately, while } \\
\text { occasionally overusing } \\
\text { certain lexis. }\end{array}$ \\
\hline & & & & $\begin{array}{l}\text { Uses simple grammatical } \\
\text { forms with a good } \\
\text { degree of control. }\end{array}$ \\
\hline & & & & $\begin{array}{l}\text { While errors are } \\
\text { noticeable, meaning can } \\
\text { still be determined. }\end{array}$ \\
\hline 2 & \multicolumn{4}{|c|}{ Performance shares features of bands 1 and 3} \\
\hline \multirow[t]{4}{*}{1} & $\begin{array}{l}\text { Irrelevances and } \\
\text { misinterpretation of task may }\end{array}$ & \multirow{4}{*}{$\begin{array}{l}\text { Produces text that } \\
\text { communicates simple } \\
\text { ideas in simple ways. }\end{array}$} & \multirow{4}{*}{$\begin{array}{l}\text { Text is connected } \\
\text { using basic, high- } \\
\text { frequency linking } \\
\text { words. }\end{array}$} & $\begin{array}{l}\text { Uses basic vocabulary } \\
\text { reasonably appropriately. }\end{array}$ \\
\hline & & & & Uses simple \\
\hline & \multirow[t]{2}{*}{$\begin{array}{l}\text { Target reader is minimally } \\
\text { informed. }\end{array}$} & & & $\begin{array}{l}\text { grammatical forms with } \\
\text { some degree of control. }\end{array}$ \\
\hline & & & & $\begin{array}{l}\text { Errors may impede } \\
\text { meaning at times. }\end{array}$ \\
\hline
\end{tabular}

0 Content is totally irrelevant.

Performance below band 1

Target reader is not informed 